\title{
Imagens Ultra-Sonográficas do Plexo Braquial na Região Axilar*
}

\section{Ultrasound Images of the Brachial Plexus in the Axillary Region}

\author{
Diogo Brüggemann da Conceição ${ }^{1}$, Pablo Escovedo Helayel, TSA ${ }^{1}$, Francisco Amaral Egydio de Carvalho²,
} Jaderson Wollmeister ${ }^{2}$, Getúlio Rodrigues de Oliveira Filho, TSA ${ }^{1}$

\section{RESUMO}

Conceição DB, Helayel PE, Carvalho FAE, Wollmeister J, Oliveira Filho GR - Imagens Ultra-Sonográficas do Plexo Braquial na Região Axilar.

JUSTIFICATIVA E OBJETIVOS: A artéria axilar é referência anatômica de superfície para o bloqueio do plexo braquial por via axilar. Estudos anatômicos sugerem variabilidade das posições das estruturas nervosas do plexo braquial em relação à artéria. Essas variações podem dificultar bloqueios por neuroestimulação. A ultrasonografia permite a identificação das estruturas do plexo braquial ${ }^{1}$. Este estudo visou a descrever o posicionamento dos nervos do plexo braquial em relação à artéria axilar.

MÉTODO: Foram estudados 30 voluntários de ambos os sexos, em posição supina com abdução a $90^{\circ}$ e rotação externa do ombro e flexão do cotovelo a $90^{\circ}$. Utilizando transdutor digital de $5 \mathrm{~cm}$ e 5-10 $\mathrm{MHz}$, foram identificados os nervos mediano, ulnar e radial e as respectivas posições em relação à artéria foram marcadas em uma carta gráfica seccional de oito setores, numerados em ordem crescente a partir da hora 12 (medial), cujo centro representava a artéria axilar.

RESULTADOS: O nervo mediano localizou-se predominante no setor 8 (55\%) e no setor 1 (28\%) (mediais); o nervo radial localizou-se predominantemente nos setores 4 (59\%) e 5 (34\%) (laterais) e o nervo ulnar nos setores 2 e 3 (inferiores) em $69 \%$ e $24 \%$ dos casos, respectivamente. Houve considerável variação da localização dos nervos em relação aos aspectos superior e inferior da artéria.

CONCLUSÕES: A inspeção em tempo real, por ultra-som, das estruturas neurovasculares do plexo braquial na axila mostrou que os nervos mediano, ulnar e radial podem apresentar diferentes relações com a artéria axilar.

\footnotetext{
*Recebido do (Received from) Núcleo de Ensino e Pesquisa em Anestesia Regional do Hospital Governador Celso Ramos, CET Integrado de Anestesiologia da SES-SC, Florianópolis, SC
}

1. Anestesiologista do CET Integrado de Anestesiologia da SES-SC; Membro do Núcleo de Ensino e Pesquisa em Anestesia Regional do HGCR

2. ME ${ }_{2}$ do CET Integrado de Anestesiologia da SES-SC

Apresentado (Submitted) em 12 de dezembro de 2006

Aceito (Accepted) para publicação em 21 de agosto de 2007

Endereço para correspondência (Correspondence to):

Dr. Diogo Brüggemann da Conceição

Rua Bocaiúva, 1.659/1.103

88015-530 Florianópolis, SC

E-mail: diconceicao@hotmail.com

(C) Sociedade Brasileira de Anestesiologia, 2007
Unitermos: ANATOMIA: plexo braquial; ULTRA-SONOGRAFIA: sistema nervoso periférico.

\section{SUMMARY}

Conceição DB, Helayel PE, Carvalho FAE, Wollmeister J, Oliveira Filho GR -Ultrasound Images of the Brachial Plexus in the Axillary Region.

BACKGROUND AND OBJECTIVES: The axillary artery is the anatomical reference, in the surface, for axillary brachial plexus block. Anatomic studies suggest variability in the location of the structures in the brachial plexus in relation to the axillary artery. These variations can hinder blocks by neurostimulation. The ultrasound allows the identification of the structures within the brachial plexus ${ }^{1}$. The objective of this report was to describe the position of the nerves in the brachial plexus in relation to the axillary artery.

METHODS: Thirty volunteers of both genders were studied. They were in the supine position with $90^{\circ}$ abduction and external rotation of the shoulder and 90 flexion of the elbow. Using a $5 \mathrm{~cm}$ and 5 $10 \mathrm{MHz}$ digital transducer, median, ulnar and radial nerves were identified and their position in relation to the artery were recorded in an 8-sector sectional graphic chart, numbered in crescent order starting at the 12-hour position (medial), whose center represented the axillary artery.

RESULTS: The median nerve was located mainly in sectors 8 (55\%) and 1 (28\%) (medial); the radial nerve was predominantly in sectors 4 (59\%) and 5 (34\%) (lateral); and the ulnar nerve in sectors 2 and 3 (inferior) in $69 \%$ and $24 \%$ of the cases, respectively. There was a considerable variation in the location of the nerves in relation to the superior and inferior aspects of the artery.

CONCLUSIONS: Real-time ultrasound inspection of the neurovascular structures of the brachial plexus in the axilla demonstrated that the median, ulnar and radial nerves have different relations with the axillary artery.

Key Words: ANATOMY: brachial plexus; ULTRASOUND: peripheral nervous system.

\section{INTRODUÇÃO}

São descritas várias formas de abordagem ao plexo braquial dentro das técnicas de Anestesia Regional. A forma de abordagem é escolhida de acordo com a localização em que será realizada a intervenção cirúrgica no membro superior. O bloqueio utilizando a via axilar é indicado, sobretudo, para procedimentos no antebraço, no punho e na mão. Seu 
índice de sucesso depende da localização correta das estruturas nervosas em relação às referências anatômicas, do posicionamento adequado da agulha e da dispersão do anestésico local ao redor dos nervos ${ }^{1-3}$.

Os livros clássicos de anatomia e os diversos estudos já realizados com o objetivo de avaliar as possíveis causas de falha utilizaram, na maioria das vezes, cadáveres como modelo anatômico, que apresentam diferenças na tensão e rigidez das estruturas quando comparadas com as estruturas in vivo. Além disso, os métodos de conservação podem ser responsáveis por distorções dessas estruturas ${ }^{4}$.

Considerando essas observações e sabendo da existência de poucos trabalhos utilizando ultra-sonografia para identificação das estruturas anatômicas envolvendo o plexo braquial na região axilar, foi realizado o presente estudo em voluntários saudáveis com o objetivo de avaliar a posição dos principais nervos do plexo braquial na região axilar em relação à artéria axilar.

\section{MÉTODO}

Após aprovação do Comitê de Ética e Pesquisa do Hospital Governador Celso Ramos obteve-se o consentimento verbal informado de 30 pacientes voluntários, com idades entre 18 e 67 anos, estado físico ASA I, de ambos os sexos, incluídos para exame ultra-sonográfico do plexo braquial no nível axilar.

Para realização do exame o braço foi posicionado como descrito por Winnie": paciente em posição supina, com braço abduzido em $90^{\circ}$ em relação ao tronco e antebraço fletido em $90^{\circ}$ em relação ao braço e em rotação externa.

As imagens foram coletadas com um aparelho portátil de ultra-sonografia (Titan, Sonosite) equipado com um transdutor digital linear de banda larga $(5-10 \mathrm{mHz})$, com $5 \mathrm{~cm}$ de comprimento, sendo as imagens armazenadas em cartão de memória (compact flash).

O transdutor foi colocado transversalmente sobre a pele da região axilar na parte interna do braço e posicionado até mostrar a imagem referente à intersecção do músculo peitoral maior e bíceps braquial. Só então foi iniciada a individualização das estruturas do feixe vasculonervoso (Figura 1). O exame foi realizado por dois anestesiologistas experientes em bloqueios guiados por ultra-som, que identificaram a artéria axilar e os nervos radial, mediano e ulnar, e anotaram suas posições.

Para relacionar os nervos à artéria axilar, a região a ser estudada foi dividida em oito setores e disposta num círculo, com a artéria correspondendo ao centro (Figura 2). Para documentação foi usada uma folha para transparência $(16 \times$ $20 \mathrm{~cm}$ ) com o círculo desenhado sobre ela.

A folha de transparência foi posicionada sobre a tela do monitor do equipamento de ultra-som, de maneira que o centro do gráfico correspondesse exatamente à artéria axilar e o bordo superior da folha estivesse paralelo à margem

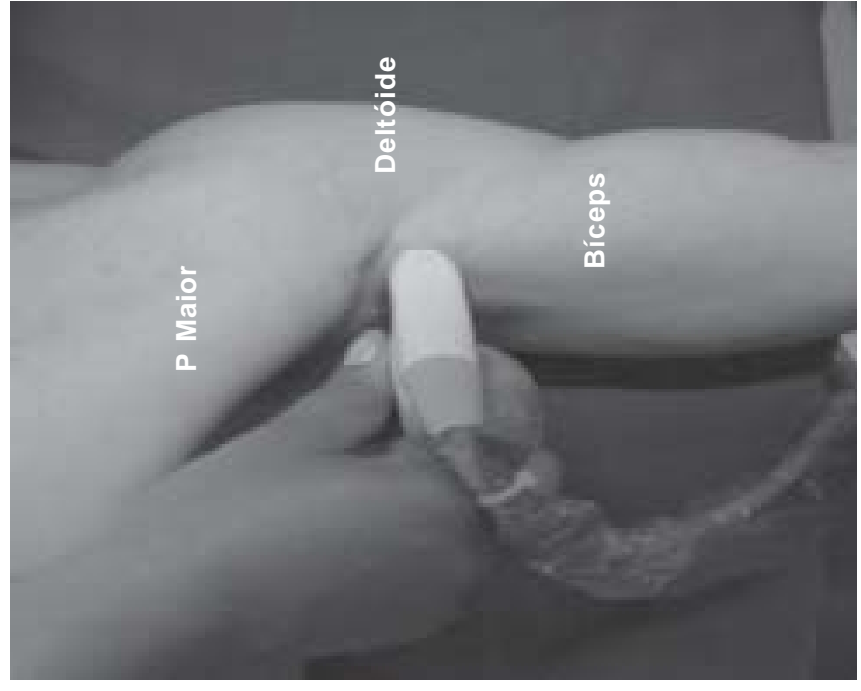

Figura 1 - Posição do Transdutor.

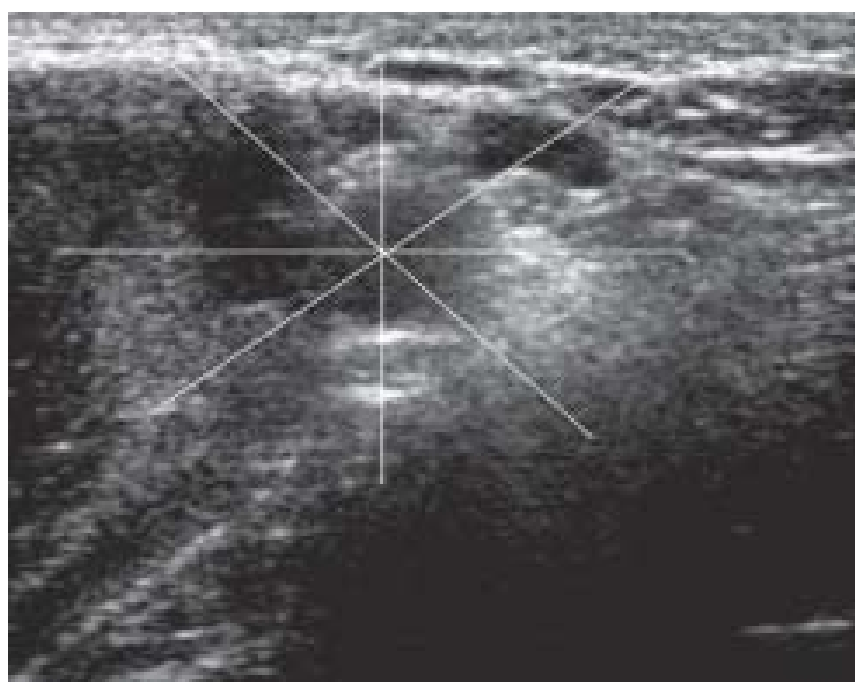

Figura 2 - Divisão dos Setores e Sua Relação com a Artéria Axilar.

superior da tela. Assim, determinava-se em qual setor do gráfico cada nervo estava localizado.

Os dados foram analisados empregando-se estatística descritiva, sendo expressos na forma de porcentagens.

\section{RESULTADOS}

Foram examinados 29 pacientes voluntários. Os dados demográficos estão dispostos na tabela I. Um paciente negouse a ser examinado no momento do exame e foi excluído. Em todos os pacientes estudados foram identificados os nervos: mediano localizado no setor 8 em 55\% dos pacientes e no setor 1 em $28 \%$ (Figura 3); nervo radial no setor 4 em 59\% dos pacientes e no setor 5 em 34\% (Figura 4); nervo ulnar no setor 2 em 69\%; e no 3 em 24\% (Figura 5). 
Tabela I - Dados Demográficos

\begin{tabular}{lcc}
\hline Parâmetro & Média \pm DP \\
\hline Idade (anos) & $18-67$ & $34 \pm 14,39$ \\
Sexo $(\mathrm{M} / \mathrm{F})$ & $21 / 8$ & \\
Peso $(\mathrm{kg})$ & $45-94$ & $72,93 \pm 14,39$ \\
Altura $(\mathrm{cm})$ & $150-186$ & $171,48 \pm 9,57$ \\
$\begin{array}{l}\text { Circunferência do } \\
\text { braço }(\mathrm{cm})\end{array}$ & $20-42$ & $31,07 \pm 5,7$ \\
\hline
\end{tabular}

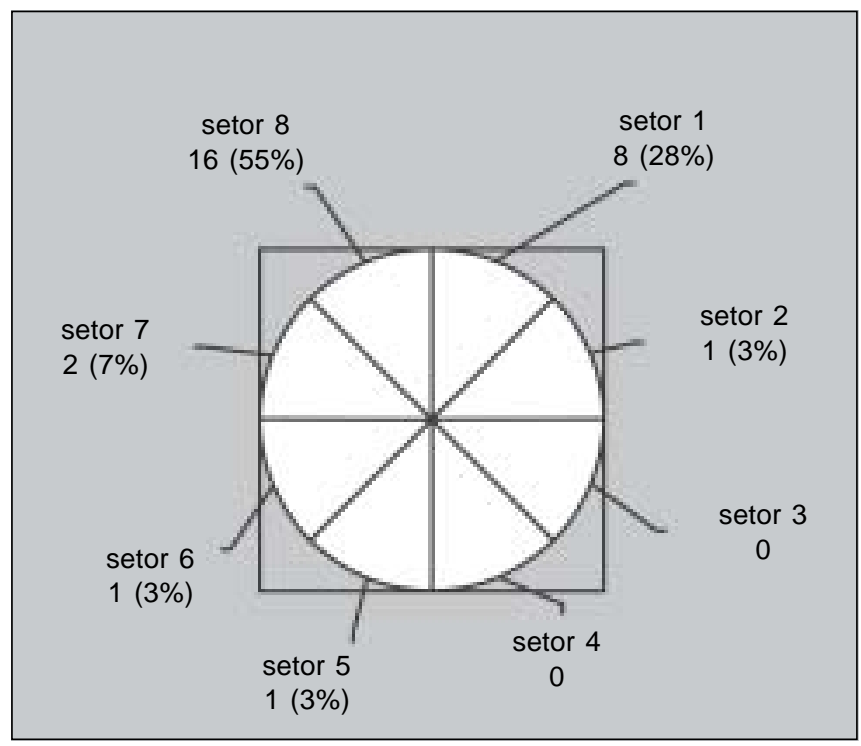

Figura 3 - Distribuição das Localizações do Nervo Mediano.

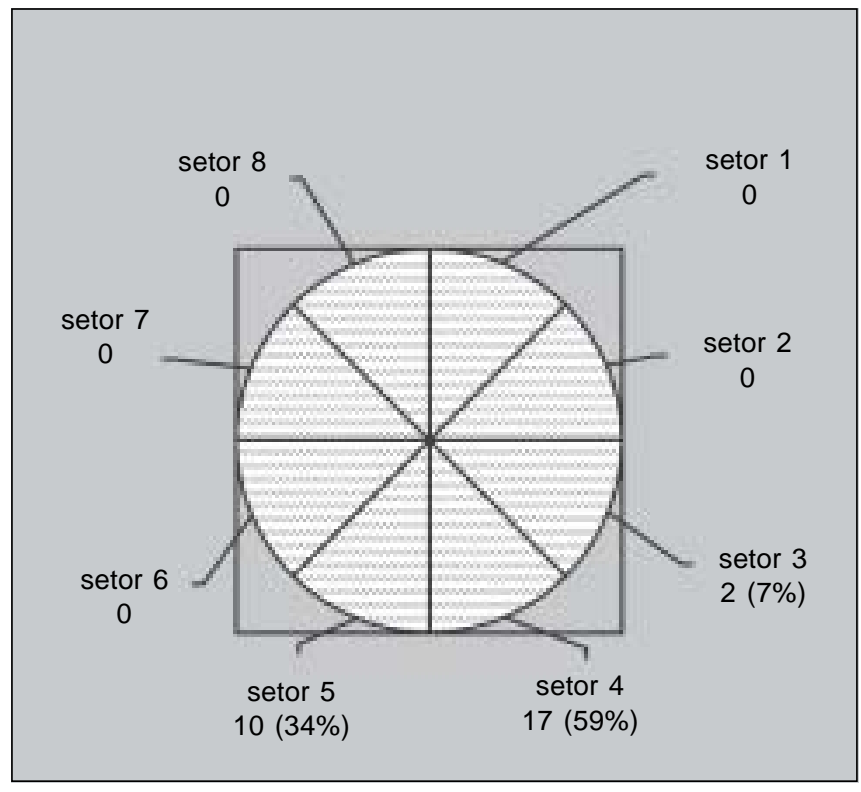

Figura 4 - Distribuição das Localizações do Nervo Radial.

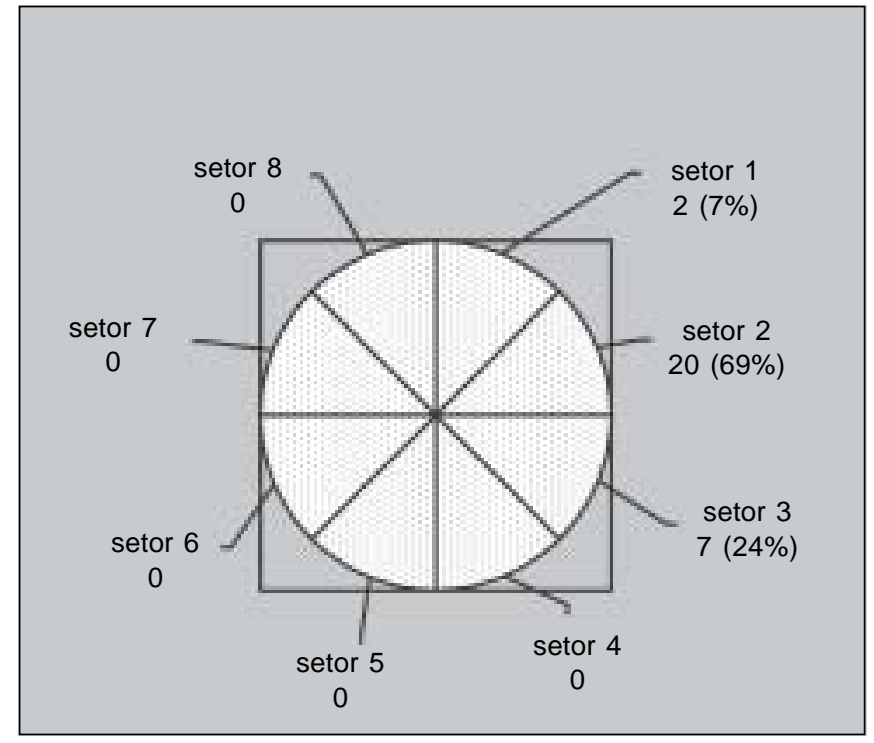

Figura 5 - Distribuição das Localizações do Nervo Ulnar.

\section{DISCUSSÃo}

A ultra-sonografia vem sendo considerada forma eficiente de identificação de estruturas nervosas, podendo tornar-se poderosa ferramenta auxiliar na realização dos bloqueios periféricos.

Neste estudo pode-se observar que a ultra-sonografia mostrou-se útil na identificação dos nervos terminais do plexo braquial na região axilar. Quando se usa o auxílio da ultrasonografia em bloqueio do plexo braquial por via axilar, visualiza-se primeiro a artéria axilar, as veias e os músculos que cercam a bainha do plexo. Após, identificam-se as estruturas nervosas, introduzindo-se a agulha e depositando o anestésico local ao redor de cada nervo. Os nervos aparecem, em cortes ultra-sonográficos transversos, como nódulos hipoecóicos misturados a um tecido hiperecóico, como demonstrado por Silvestri e col. 5,6. Para o bloqueio efetivo do plexo braquial na região axilar é necessário o conhecimento da exata localização de cada um dos nervos. As posições anatômicas mostradas em livros-texto são determinadas por meio de dissecção em cadáveres. Entretanto, há diferenças entre o tecido cadavérico e de pacientes, além de variações anatômicas ${ }^{4}$.

No presente estudo, apesar do número pequeno de pacientes, foram encontradas variações na posição dos nervos radial, mediano e ulnar em relação à artéria axilar. $\mathrm{O}$ impacto dessas variações para o sucesso clínico dos bloqueios realizados por métodos que dependem de referências anatômicas de superfície, palpação ou cliques fasciais é desconhecido; todavia, seria indescartável a suposição de que esse fato possa contribuir para possíveis falhas nos bloqueios do plexo braquial.

Alguns estudos propõem a existência de septos dividindo 0 plexo braquial na região axilar ${ }^{3}$. $\mathrm{O}$ transdutor usado no pre- 
sente estudo tem alta freqüência (5 a $10 \mathrm{MHz}$ ), permitindo a identificação de estruturas nervosas. Entretanto, não foi possível identificar a presença de bainha ou septos limitando o plexo braquial.

Concluindo, a ultra-sonografia de alta resolução foi capaz de identificar as estruturas neurovasculares do plexo braquial no nível axilar em todos os pacientes, confirmando grande variabilidade na posição dos nervos em relação à artéria axilar.

\section{Ultrasound Images of the Brachial Plexus in the Axillary Region}

Diogo Brüggemann da Conceição, M.D.; Pablo Escovedo Helayel, TSA, M.D.; Francisco Amaral Egydio de Carvalho, M.D.; Jaderson Wollmeister, M.D.; Getúlio Rodrigues de Oliveira Filho, TSA, M.D.

\section{INTRODUCTION}

Several approaches to the brachial plexus are described within the techniques of Regional Blocks. The approach is chosen according to the location of the surgery in the upper limb. The axillary approach is indicated, especially, for surgeries in the forearm, wrist, and hand. Its success rate depends on the correct location of the nerves in relation to the anatomic references, adequate positioning of the needle, and dispersion of the local anesthetic around the nerves ${ }^{1-3}$. Classic anatomy books and several studies undertaken to evaluate the possible causes of failure used, in most cases, cadavers as anatomic models; however, there are differences in tone and rigidity of the structures in cadavers when compared with living structures. Besides, conservation methods might be responsible for distortion of those structures ${ }^{4}$.

Taking those observations in consideration and knowing that few works have used ultrasound to identify anatomic structures involved in the brachial plexus in the axilla, the present study in healthy volunteers was undertaken to evaluate the position of the main nerves of the brachial plexus in the axilla in relation to the axillary artery.

\section{METHODS}

After approval by the Ethics and Research Commission of the Hospital Governador Carlos Ramos, 30 volunteers of both genders, ages 18 to 67 years, physical status ASA I, gave their oral consent and were scheduled for ultrasound of the brachial plexus in the axilla.

For the exams, the arm was positioned according to the description of Winnie: patient in the supine position with the arm in a $90^{\circ}$ abduction in relation to the trunk and forearm with a $90^{\circ}$ flexion in relation to the arm and in external rotation.
The exam was done with a portable ultrasound device (Titan, Sonosite) with a $5 \mathrm{~cm}$ wide band $(5-10 \mathrm{MHz}$ ) linear digital transducer and the images were stored in a memory card (compact flash).

The transducer was transversal to the skin in the axillary region, in the internal portion of the arm, and positioned until it showed the intersection of the pectoral major and biceps muscles. Individualization of the structures in the vascularnerve plexus (Figure 1) was then initiated.

The exam was performed by two experienced anesthesiologists in ultrasound guided blocks, who identified the axillary artery and radial, median and ulnar nerves, recording their position.

To relate the nerves to the axillary arteries, the study region was divided in 8 sectors and placed in a circle with the artery in the center (Figure 2). A transparent sheet $(16 \times 20 \mathrm{~cm})$ with the circle was used to record the results.

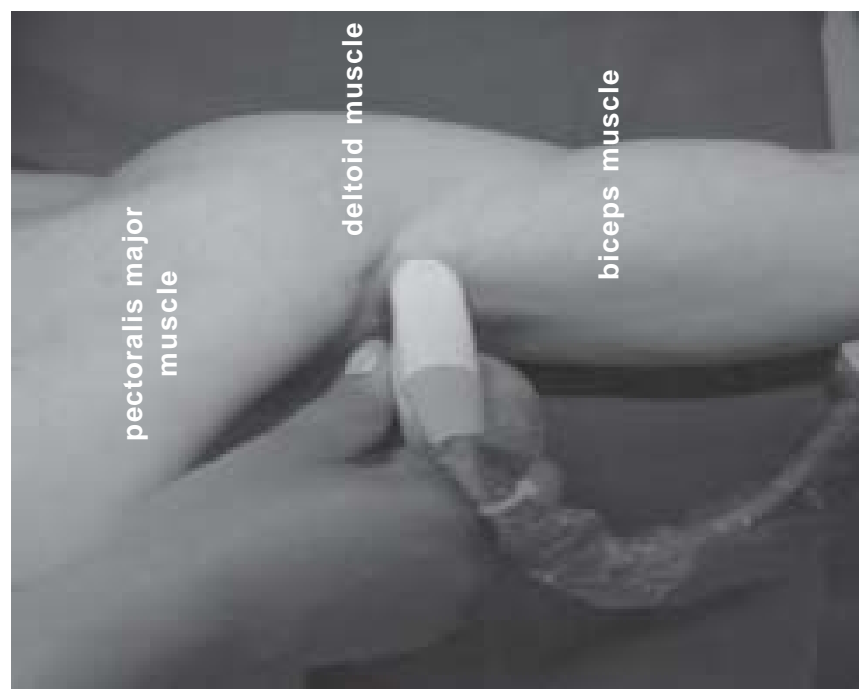

Figure 1 - Position of the transducer.

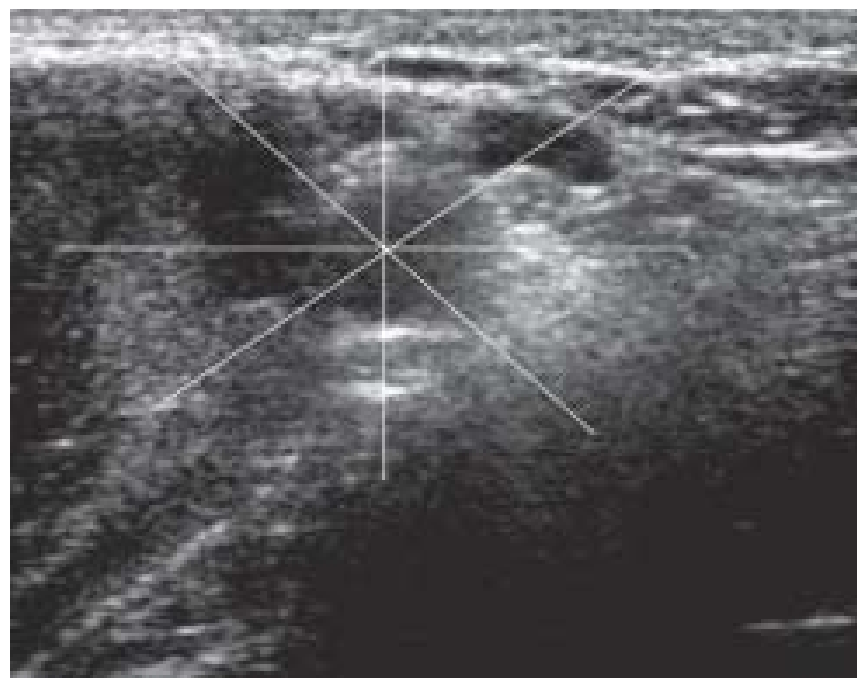

Figure 2 - Sector division and its relationship with the axillary artery. 
The transparency was placed on the screen of the ultrasound equipment so the center of the graphic corresponded to the axillary artery and the upper margin of the sheet was parallel to the upper margin of the screen. This was used to determine in which sector of the graphic each nerve was located. The data were analyzed using descriptive statistics and expressed as percentages.

\section{RESULTS}

Twenty-nine volunteers were examined. Table I shows the demographic data. One patient refused to be examined and was excluded from the study.

The nerves were identified in every patient: median in sector 8 in $55 \%$ of the patients and in sector 1 in $28 \%$ (Figure 3); radial nerve in sector 4 in $59 \%$ of the patients and in sector 5 in 34\% (Figure 4); and the ulnar nerve in sector 2 in $69 \%$ and in sector 3 in $24 \%$ (Figure 5).

Table I - Demographic Data

\begin{tabular}{lcc}
\hline Parameter & Mean \pm SD \\
\hline Age (years) & $18-67$ & $34 \pm 14.39$ \\
Gender (M/F) & $21 / 8$ & \\
Weight (kg) & $45-94$ & $72.93 \pm 14.39$ \\
Height (cm) & $150-186$ & $171.48 \pm 9.57$ \\
Arm circumference & $20-42$ & $31.07 \pm 5.7$ \\
$(\mathrm{~cm})$ & & \\
\hline
\end{tabular}

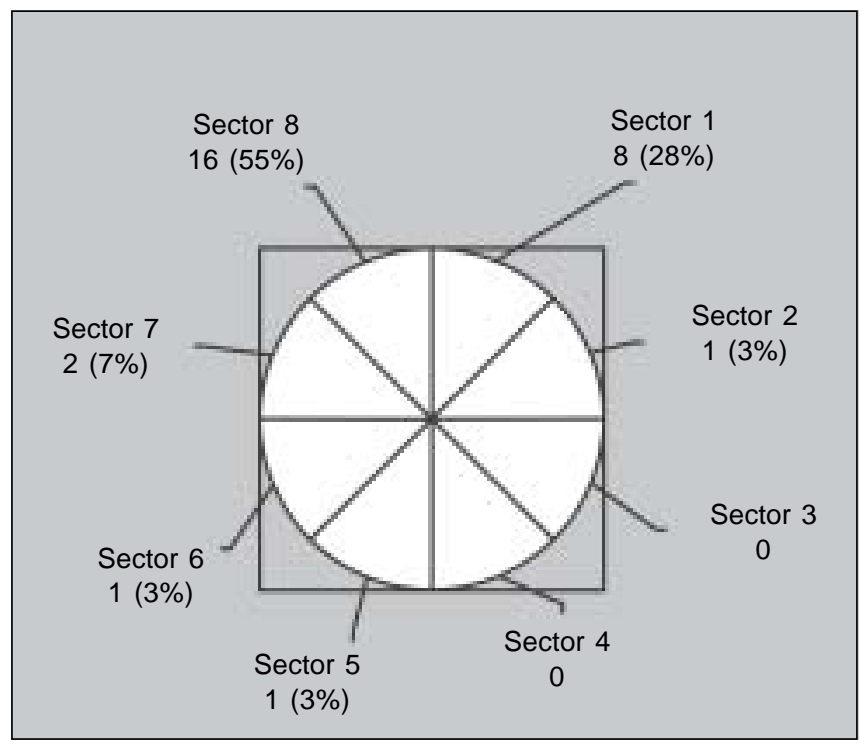

Figure 3 - Distribution of the Localizations of the Median Nerve.

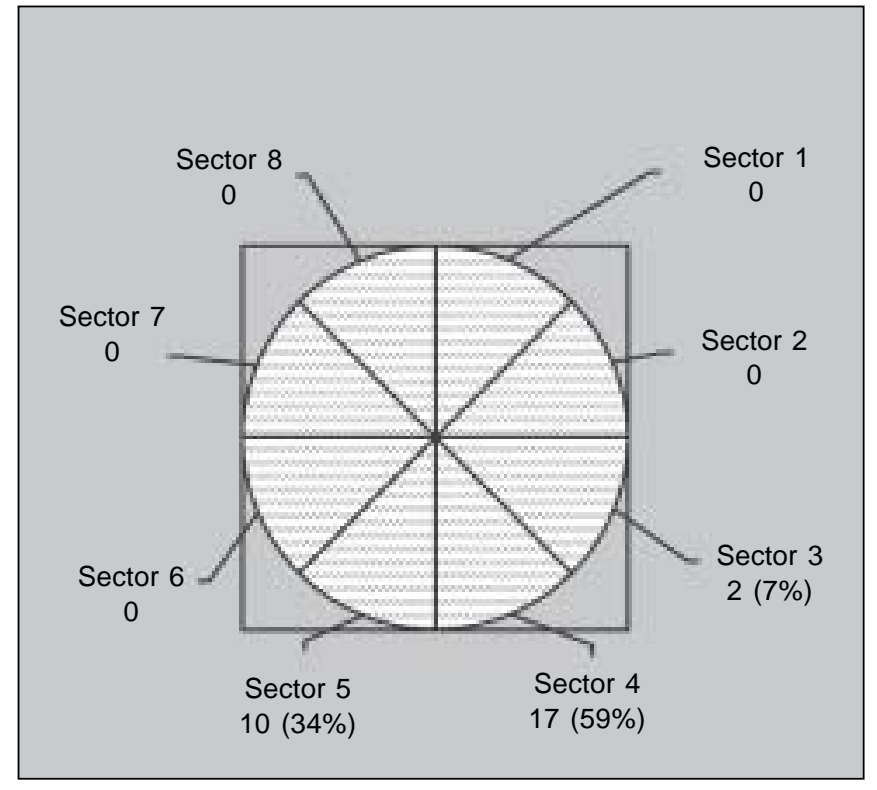

Figure 4 - Distribution of the Localizations of the Radial Nerve.

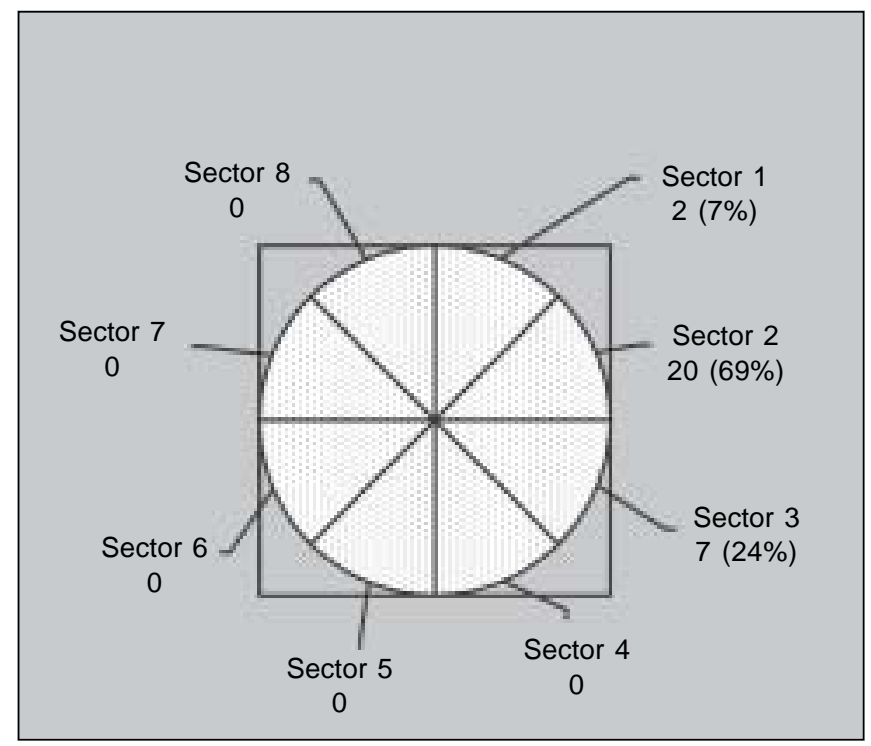

Figure 5 - Distribution of the Localizations of the Ulnar Nerve.

\section{DISCUSSION}

The ultrasound has been considered an efficient method to identify nerve structures and it can be a powerful tool in peripheral blocks.

In this study, it was observed that the ultrasound was useful in identifying the terminal nerves of the brachial plexus in the axilla. When ultrasound is used in axillary brachial plexus blocks, the axillary artery, veins and muscles that surround the sheath of the nerve are visualized first. Afterwards, the nerve structures are identified, the needle is introduced, and 
the local anesthetic is deposited around each nerve. The transverse image of nerves in the ultrasound appear as hyperechoic nodules mixed with a hypoechoic tissue, as demonstrated by Silvestri et al. ${ }^{5,6}$ For the effective blockade of the brachial plexus in the axillary region, the knowledge of the exact position of each nerves is necessary. The anatomic positions showed in textbooks are determined by dissecting cadavers. But, besides anatomic variations, there are differences between the cadaveric tissue and living tissue ${ }^{14}$. The present study, despite the small number of patients, demonstrated variations in the position of the radial, median and ulnar nerves in relation to the axillary artery. The impact of these variations for the clinical success of the blockades done by methods that depend on surface anatomical references, palpation, or fascial clicks is unknown. However, one cannot discard that this might contribute to possible failures in brachial plexus blocks.

Some studies propose the presence of septa dividing the brachial plexus in the axilla ${ }^{3}$. In this study we used a high frequency (5 to $10 \mathrm{MHz}$ ) transducer, which allows the identification of nerve structures. However, it was not possible to identify the presence of sheath or septa in the brachial plexus. To conclude, high-resolution ultrasound was capable of identifying the neurovascular structures in the axillary region of all patients, confirming the great variability in nerve position in relation to the axillary artery.

\section{REFERÊNCIAS - REFERENCES}

01. Retzl G, Kapral S, Greher M et al. - Ultrasonographic findings of the axillary part of the brachial plexus. Anesth Analg, 2001; 92:1271-1275.

02. De Andrés J, Sala-Blanch X - Ultrasound in the practice of brachial plexus anesthesia. Reg Anesth Pain Med, 2002;27:77-89.

03. Ting PL, Sivagnanaratnam V - Ultrasonographic study of spread of local anaesthetic during axillary brachial plexus block. Br J Anaesth, 1989;63:326-329.

04. Partridge $\mathrm{BL}$, Katz J, Benirschke $\mathrm{K}$ - Functional anatomy of the brachial plexus sheath: implication for anesthesia. Anesthesiology, 1987;66:743-747.
05. Silvestri E, Martinoli C, Derchi LE et al. - Echotexture of peripheral nerves: correlation between US and histologic findings and criteria to differentiate tendons. Radiology, 1995;197:291-296.

06. Yang WT, Chui PT, Metreweli C - Anatomy of the normal brachial plexus revealed by sonography and the role of sonographic guidance in anesthesia of the brachial plexus. AJR, 1998;171: 1631-1636.

\section{RESUMEN}

Conceición DB, Helayel PE, Carvalho FAE, Wollmeister J, Oliveira FiIho GR - Imágenes Ultra-Sonográficas del Plexo Braquial en la Región Axilar.

JUSTIFICATIVA Y OBJETIVOS: La arteria axilar es una referencia anatómica de superficie para el bloqueo del plexo braquial por vía axilar. Estudios anatómicos sugieren variabilidad de las posiciones de las estructuras nerviosas del plexo braquial con relación a la arteria. Esas variaciones pueden dificultar bloqueos por neuro estimulación. El ultrasonido permite la identificación de las estructuras del plexo braquial ${ }^{~}$. Ese estudio buscó describir el posicionamiento de los nervios del plexo braquial con relación a la arteria axilar.

MÉTODO: Fueron estudiados 30 voluntarios de los dos sexos, en posición supina con abducción a $90^{\circ}$ y rotación externa del hombro y flexión del codo a $90^{\circ}$. Utilizando transductor digital de $5 \mathrm{~cm}$ y 5 $10 \mathrm{MHz}$, fueron identificados los nervios mediano, ulnar y radial, $y$ las respectivas posiciones en relación a la arteria fueron marcadas en una carta gráfica seccional de 8 sectores, enumerados en orden creciente a partir de la hora 12 (medial), cuyo centro representaba la arteria axilar.

RESULTADOS: El nervio mediano se ubicó predominante en el sector 8 (55\%) y en el sector 1 (28\%) (mediales); el nervio radial se ubicó predominantemente en los sectores 4 (59\%) y 5 (34\%) (laterales) y el nervio ulnar en los sectores 2 y 3 (inferiores) en un $69 \%$ y un $24 \%$ de los casos, respectivamente. Hubo una considerable variación de la localización de los nervios con relación a los aspectos superior e inferior de la arteria.

CONCLUSIÓN: La inspección en tiempo real, por ultrasonido, de las estructuras neuro vasculares del plexo braquial en la axila mostró que los nervios mediano, ulnar y radial pueden presentar diferentes relaciones con la arteria axilar. 